Archivum, LXIV, 2014, pp. 127-156

\title{
La tradición novelística en La familia de Pascual Duarte
}

Recibido: 9/11/2013

Aceptado: 26/02/2014

\section{RESUMEN:}

Este trabajo procura situar La familia de Pascual Duarte en el desarrollo de la novela española de la primera mitad del siglo XX. Se señala primeramente su entronque con las novelas prototremendistas de la España nacional durante la Guerra, especialmente las de Iribarren, Borrás, García Serrano, García Suárez y Carretero Novillo. Se considera después sus similitudes con la picaresca de La busca de Baroja. Por último se repara en el uso de la ironía merced al principio de la denominada novela jánica y que tiene en San Manuel Bueno, mártir de Unamuno su precedente más inmediato. De esta suerte, se presenta Pascual Duarte no como el inicio de la novela de postguerra, sino como la continuación del realismo picaresco de Baroja, la novela jánica de Unamuno y el tremendismo desarrollado en la España nacional.

PALABRAS CLAVE: Cela, Pascual Duarte, tremendismo, novela, postouerra.

\section{ABSTRACT:}

This article considers the place of La familia de Pascual Duarte in the course of the Spanish novel during the first half of the twentieth century. Firstly, it considers how this novel follows in the footsteps of the pre-tremendista works published in National Spain during the Civil War, namely those by Iribarren, Borrás, García Serrano, García Suárez and Carretero Novillo. Secondly, it examines its affinities with Baroja's picaresque novel La busca. Thirdly, it underscores its irony in the fashion of the Janus- 
faced novel, whose most immediate precedent was Unamuno's San Manuel Bueno, mártir. Accordingly, this piece submits that, not only does Pascual Duarte mark the beginning of the post-war novel, but it was written in the wake and fashion of Baroja's previous picaresque works, Unamuno's Janus-faced fiction, and the tremendista novels published by the supporters of the National army.

KEY WORDS: Cela, Pascual Duarte, tremendismo, novel, post-war

Los pareceres de la filología en torno a La familia de Pascual Duarte se han manifestado unánimes en cuanto a su mucha relevancia en la historia de la novela española ${ }^{1}$. Publicada en 1942, su calidad literaria y el favor imperecedero de lectores y estudiosos le han deparado consideración de ser la obra inaugural de la novela de postguerra. Se la ha venido presentado y ensalzando como paradigma del tremendismo, como obra insignia de esa modalidad novelística de vuelo tan corto que se reduce a la década de los cuarenta, pero así también como predecesora del realismo social que el mismo Cela abanderaría poco después con La colmena (1951). Cuando se ha investigado su prosapia en la tradición novelística española, se la ha emparentado ipso facto con la picaresca del Siglo de Oro. El objeto de este breve trabajo reside en ofrecer una aproximación al lugar de Pascual Duarte como obra inserta en el contexto de toda la primera mitad del siglo XX, como novela que sigue una tradición trazada y establecida por sus antecesores recientes e inmediatos ${ }^{2}$, fundamentalmente la literatura

1 Entre los estudios en torno a Cela que tratan las beldades literarias de Pascual Duarte figuran, además de los que aquí se irán citando: Zamora Vicente, Alonso: Camilo José Cela. Acercamiento a un escritor, Madrid, Gredos, 1962; Ilie, Paul: La novelística de Camilo José Cela, Madrid, Gredos, 1962; Kirsner, Robert: The Novels and Travels of Camilo José Cela, Chapel Hill, University of North Carolina Press, 1963; Foster, David W.: Form of the Novel in the Works of Camilo José Cela, Columbia, University of Missouri Press, 1967; Suárez, Sara: El léxico de Camilo José Cela, Madrid, Alfaguara, 1969; Wasserman, Carol: Camilo José Cela y su trayectoria literaria, Madrid, Playor, 1990; Blanco Vila, Luis: Para leer a Camilo José Cela, Madrid, Palas Atenea, 1991; Platas Tasende, Ana María: Camilo José Cela, Madrid, Síntesis, 2005.

2 Y escribo aproximación porque el tema pudiera dar para desarrollar un estudio mucho más extenso de lo que permite la extensión de un artículo. 
prototremendista de la Guerra Civil y, antes, la picaresca de Baroja y la novela modernista de Unamuno. Primero repasaré brevemente su lugar en el tremendismo, antes de considerarla como obra continuadora de las corrientes novelísticas que la preceden.

La crítica ha gustado de enjuiciar Pascual Duarte en función de sus temáticas y ambientes, lo cual se ha prestado de cuando en cuando a interpretaciones conflictivas. Las apreciaciones más superficiales han incidido en presentarla como obra espejo de la sociedad de la postguerra. En virtud de tal lectura, Pascual Duarte podría tenerse como el principal representante del tremendismo y como uno de los exiguos textos de interés en su década. Ello la arrincona a veces e inicuamente en un lugar sombrío en las historias de la literatura española. El Companion to the Twentieth Century Spanish Novel de Támesis, publicado en 2008, ejemplifica esta actitud e, implícitamente, pone en aviso de cómo una lectura meramente social reduce injustamente el valor de esta obra. En la introducción a dicho volumen se afirma que Pascual Duarte y Nada "Both attest to resentments simmering beneath the surface throughout centuries of autocratic rule and still unexorcised" ${ }^{3}$. La primera novela de Cela apenas merece dos lacónicas menciones en sendos capítulos de ese Companion; en uno de los cuales se dice de ella y de La colmena que "contrived to capture some of the despair and vanality of everyday life in a society both provincial and backwards" ${ }^{\prime \prime}$. Tales impresiones, apuntadas tan de soslayo, hacen poca justicia a un texto que merece tenerse como uno de los ejemplos capitales de la novela de todo el siglo XX, pero ilustran ese reduccionismo a que algunos la han condenado. Permítanseme sendos apuntes al respecto.

Primero. Presentarla como ejemplo de los resentimientos subyacentes durante siglos (supra) supone caer en el ralo y manido

3 Alisent, Marta E.: "Introducción", en Marta E. Alisent (ed.), A Companion to the Twentieth Century Spanish Novel. Londres, Támesis, 2008, págs. 1-16, 4.

4 Navajas, Gonzalo: "The Spanish Novel in the Twentieth Century", en Marta E. Altisent, A Companion to the Twentieth Century Spanish Novel, págs. 17-29, 24. 
tópico de la España negra y goyesca, donde los españoles vivían carcomidos por un insano y atávico odio contra todo cuanto los rodeaba. No es esa, por cierto, la imagen de España que hallamos en una parte importante de nuestra tradición literaria. A cualquier conocedor de la literatura española se le vendrán a mientes infinitud de obras que han celebrado el presente y el pasado de España, v.g., las novelas cortas de Zayas, en que se ensalza y describe el lujo de la corte imperial; El sí de las niñas de Moratín, en que los personajes aprenden felizmente la lección que se les presenta, o el idealismo romántico de Bécquer, quien nos pinta un pasado centenario heroico e idealizado. Antes al contrario, esa visión apabullantemente pesimista plasmada en Pascual Duarte debe verse como continuación de la literatura naturalista, gestada a finales del siglo XIX, que refleja los ambientes sociales más difíciles, así en España - piénsese, naturalmente, en Galdós y en Pardo Bazán, además de en gentes como Alejandro Sawa o Juan Bautista Amorós (conocido por el pseudónimo "Silverio Lanza") - como en el resto de Europa, v.g. con Zola, Stendhal, Flaubert, Dickens, Ibsen, etc ${ }^{5}$. No se trata, en absoluto, de un fenómeno intrínseca y exclusivamente español.

Segundo. Enjuiciarla meramente como hija de la desesperación y la pobreza de una sociedad provinciana y retrasada (supra) - en referencia expresa a la postguerra - le hace otro flaco favor y, desde luego, muy poca justicia histórica. Notorio es que la España del siglo XIX y de la mayor parte del XX - hasta el boom económico de los sesenta - fue una nación retrasada social y económicamente, tanto como pudieran serlo otras de su entorno cultural más cercano, cuales son Italia y Portugal. Si la comparamos con Inglaterra, Alemania o Dinamarca, España habrá de salir muy mal parada, pero en el conjunto europeo, su situación no era tan

5 Martínez Cachero rememora como en La Estafeta Literaria se advertía a los lectores "del serio peligro localizable en la propensión naturalista y zolesca [...] patente en escritores jóvenes como Cela - La familia de Pascual Duarte- o García Serrano - La fiel infantería -", en Martínez Cachero, José María: La novela española entre 1936 y el fin de siglo. Historia de una aventura. Madrid, Castalia, 1997, pág. 103. 
dramática ${ }^{6}$. Tampoco procede entender los ambientes como propios de la postguerra por dos razones. Primero, porque similares ambientes de pobreza y desarraigo se habían pintado en la novela de las cuatro o cinco décadas precedentes, desde Doña Perfecta de Galdós y Los pazos de Ulloa de Pardo Bazán a la novela social de los años treinta de gentes como César Arconada, Joaquín Arderíus y José Díaz Fernández ${ }^{7}$. Díaz Fernández llegó incluso a proclamar la socialización de la literatura en dos ensayos, Acerca del arte nuevo (1927) y El nuevo Romanticismo (1930). Segundo, porque Pascual Duarte se redacta en la postguerra pero retrata la España de antes, especialmente la de de 1922 - cuando Pascual mata a su madre - y la "revolución" prorrepublicana que acontece en el pueblo de Pascual en las primeras semanas de la Guerra Civil. En este sentido, y como ha demostrado meridianamente Rafael Osuna ${ }^{8}$, en Pascual Duarte se denuncia el fracaso de los sistemas judiciales (y de la sociedad) de la Restauración, por dar a Pascual segundas oportunidades cuando no las merecía, y muy especialmente la violenta represión republicana durante la Guerra Civil. Violentas fueron ambas represiones - así la nacional como la republicana - pero Cela escribe en la España nacional,

6 Sobre la ubicación de Pascual Duarte en Extremadura, en función del avance del ejército nacional en las primeras semanas de la guerra, véase Garrido Ardila, J. A.: "La patria de Pascual Duarte", Hoy, 28 de marzo de 2013, 18.

7 Merece destacar los siguientes autores y obras de ambientes sociales represivos: César Arconada con La turbina (1930), Los pobres contra los ricos (1933) y Reparto de tierras (1934), Joaquín Arderíus con Campesinos (1931) y Crimen (1934), Manuel Benavides con Un hombre de treinta años (1933) y El último pirata del Mediterráneo (1934), Andrés Caranque de Ríos con La vida difícil (1935), José Díaz Fernández con El blocao (1928) y La venus mecánica (1929).

8 Rafael Osuna: "Pascual Duarte. Asesino, miliciano, nacionalista", Ideologies and Literature, III, 1979, págs. 85-95. Sobre el calado político, véanse asimismo, y entre otros muchos, Schaefer, Claudia: “Conspiración, manipulación, conversión antigua: Pascual Duarte y la utopía histórica del Nuevo Estado Español", Anales de la Literatura Española Contemporánea, XIII, 3, 1988, págs. 261-281, y Sherzer, William: "Ideology and Interpretation in La familia de Pascual Duarte", Revista Hispánica Moderna, LV, 2, 2002, págs. 357-369. 
que se ha alzado con la victoria, y tiene un pasado nacional. En lo que a los años de la postguerra atañe, es menester reparar asimismo en que merecen una consideración mucho más honda de la que hasta la fecha se les ha conferido. Frente al panorama apocalíptico pintado en estudios y manuales como ese Companion, José Carlos Mainer ha señalado al respecto de la vida cultural de postguerra: "No fue exactamente un erial, como he recordado ya más que a menudo en estas páginas. Quien sustente que lo fue la cultura española de la postguerra tiene una visión muy simplista de algo que, por naturaleza, es complejo, como sucede en toda sociedad que ha albergado en su seno una contienda civil"

Esta suerte de balances de Pascual Duarte adoptan unas posturas, cuando menos, controvertidas, que no harán más que confundir a los lectores. Ello merece ponerse en relación con la cuestión del denominado tremendismo, definido por Jerónimo Mallo como el género de "relatos novelescos relativos a personas, hechos y situaciones verdaderamente terribles, de los que unas veces por la magnitud y otras por la acumulación de motivos de horror se recibe al leerlos una impresión 'tremenda'"10 y que también se denominó naturalismo, neo-realismo, miserabilismo o excrementicialismo ${ }^{11}$. José María Martínez Cachero explicó y contextualizó el tremendismo mejor, quizá, que ningún otro historiador de la literatura. Martínez Cachero trae a colación cómo Tomás Borrás explicaba, allá por 1944, el tremendismo como resultado de la experiencia de la Guerra Civil y de la impresión

9 Mainer, José-Carlos: La filología en el purgatorio. Los estudios literarios en torno a 1950, Barcelona, Crítica, 2003, pág. 189. Véase, del mismo autor, “La vida cultural (1936-1980)", en Domingo Ynduráin (ed.), Historia y crítica de la literatura española. Época contemporánea (1939-1980), Barcelona, Crítica, 1980, págs. 5-16.

10 Mallo, Jerónimo: “Caracterización y valor del 'tremendismo' en la novela española contemporánea", Hispania, XXXIX, 1, 1956, págs. 49-55, 49.

11 Además de Mallo, véanse al respecto, Palley, Julián: “Existencialist Trends in the Modern Spanish Novel", Hispania, XLIV, 1961, págs. 21-26; López Molina, Luis: "El tremendismo en la literatura española actual", Revista de Occidente, XLIV, 1967, págs. 372-378, además de otros que aquí iré citando. 
del recuerdo de "nuestra guerra, la revolución roja, y esta otra guerra de los demás [i.e., la Segunda Guerra Mundial]"12 antes de proponer a Cela, García Serrano y García Suárez como principales exponentes de esta tendencia. Visto desde la perspectiva de Borrás, el género respondería más bien a una reacción de los vencedores frente a los horrores de la guerra. El mismo Cela se refería a la contienda al reflexionar sobre el tremendismo: "es curioso lo espantadiza que es la gente que, después de asistir a la representación de una tragedia que duró tres años y costó ríos de sangre, encuentra tremendo lo que se aparta un ápice de lo socialmente convenido (no de la tradición literaria española)"13. Cierto es que Pascual Duarte antecede ese caudal de novelas, que podemos convenir en llamar tremendistas, de ambientes tremendos como las de García Serrano, El bosque de Ancines (1947) de Carlos Martínez Barbeito, La sombra del ciprés es alargada (1947) de Delibes, Nosotros los muertos (1948) de Manuel Sánchez Camargo, hasta Nosotros los leprosos (1950) de Luis de Castresana, Lola, espejo oscuro (1950) de Darío Fernández Flórez y Los hijos de Máximo Judas (1950) de Luis Landínez.

Pero el tremendismo, como género novelístico según las características que le han atribuido los críticos aquí mentados, no se inicia en 1942 con la primera novela de Cela, sino que se va fraguando unos años antes y cuenta con unos referentes y unos antecedentes harto conocidos. El "horror" como vehículo para causar una fuerte "impresión" había caracterizado a un sinfín de narraciones escritas y publicadas durante la Guerra Civil, especialmente en la zona nacional. La impresión de horror servía a la ideología de los nacionales en su proyecto propagandístico destinado a difundir las impiedades del denominado terror rojo. Se prodigan de esta suerte las descripciones de las persecuciones en

12 Citado en Martínez Cachero, José María: La novela española entre 1936 y el fin de siglo, pág. 118 . 117.

13 Citado en Martínez Cachero, La novela española entre 1936 y el fin de siglo, pág. 
la España republicana sufridas por los afectos al bando nacional, de las torturas a que fueron sometidos y de los asesinatos en las checas y por medio de procedimientos como los paseos. Ante esta emulsión de violencia republicana, las narraciones de los nacionales ensalzan una suerte de contraviolencia. El resultado es una corriente literaria de temáticas dominadas por el horror y la violencia y que procura causar una honda impresión en los lectores. Como ha observado Gareth Thomas, la producción novelística resultó ser mucho más prolija entre los nacionales que entre los republicanos, lo cual se debió, a decir de este crítico, al hecho de que la zona nacional crecía geográficamente según discurría la contienda y a que la mayor parte de la clase media letrada apoyaba al ejército rebelde ${ }^{14}$. Hallamos, a la sazón, un número considerable de narraciones de mensaje político y estética violenta, publicadas durante la guerra y en los meses que siguieron, que podríamos clasificar en dos apartados. Primero, las novelas de la guerra, que son evidentemente ficción inserta en el marco histórico y contemporáneo de la contienda. Segundo, una nutrida corriente de memorias de la guerra en que individuos afectos al bando nacional relatan sus experiencias en zona republicana y en las cuales detallan la persecución de que fueron objeto.

El mismo Borrás se incluía en la corriente tremendista merced a su obra Chekas de Madrid, publicada en 1940. El antecedente más claro del tremendismo quizá sea La ciudad, de Manuel Iribarren, que vio la luz en 1939. A Iribarren ha presentado Martínez Cachero de esta guisa: "es un narrador afecto al realismo y propenso al tremendismo"15. En efecto, La ciudad es ejemplo la novela de la guerra, especialmente la compuesta en el lado nacional, cada vez más aferrada a una suerte de narración de impresiones tremendas por su crudeza visual y su compromiso social e ideológico.

14 Thomas, Gareth: The Novel of the Spanish Civil War. Cambridge, Cambridge University Press, 1990, pág. 223

15 Martínez Cachero, José María: Liras entre lanzas. Historia de la Literatura Nacional en la Guerra Civil, Madrid, Castalia, 2009, pág. 305. 
"Ningún terreno más abonado para la práctica del Tremendismo que el ofrecido por el llamado 'Terror rojo' madrileño" apunta Martínez Cachero antes de listar, como ejemplo de ello, las obras de José María Carretero Novillo, Declaración de guerra (1939), El cuartel de la Montaña (1936), Nosotros los mártires (1940), La ciudad inmolada (1940) y iArriba los espectros! (1940), agrupadas todas ellas bajo el título La revolución de los patibularios ${ }^{16}$.

En efecto, el reciente estudio de Julius Ruiz sobre la represión en Madrid nos provee ahora con la constatación histórica de ese episodio de la Guerra Civil. Ruiz documenta en Madrid la organización de una estructura destinada a la identificación sistemática de elementos contrarios a la República - la denominada quinta columna - por medio de unidades, por ejemplo las del Frente Popular conocidas como "entidades antifascistas", la Dirección General de Seguridad, el Cuerpo de Investigación y Vigilancia, el Comité Provincial de Investigación Pública y la CNT-FAI (Confederación Nacional del Trabajo y la Federación Anarquista Ibérica). Entre los procedimientos de aniquilación del enemigo se contaba el establecimiento de checas de inspiración soviética, aunque los procedimientos de exterminio se asemejaban más al modus operandi de los gánsteres estadounidenses cuyos procedimientos criminales se conocían en España por medio del cine. Apunta Ruiz que "El terror de Madrid no era extrínseco al esfuerzo bélico antifascista tras el fracaso de la rebelión militar de julio de 1936. Más bien al contrario, formaba parte de él. Para asegurarse la retaguardia era necesaria una reacción organizada"17. Estas narraciones de la guerra vienen a recoger esa situación y, al concebirse la mayoría como propaganda política, propenden hacia el horror y la impresión. Además de estas novelas listadas por Martínez Cachero, existe una nómina de conocidas obras de ficción propensas al horror y la violencia y que constatan esta tendencia en el grueso de la producción no-

16 Ibid., pág. 285.

17 Ruiz, Julius: Terror rojo, Madrid, Espasa-Calpe, 2012, pág. 21. 
velística de entonces. Tales son los casos de, por ejemplo, Madrid, de corte a checa (1938) de Agustín de Foxá y de Eugenio o la proclamación de la primavera (1938) de García Serrano.

En su empeño por denunciar la represión republicana en Madrid, Foxá resalta en el título de su novela la transformación de Madrid de capital de España a una red de checas. El relato sigue la trayectoria ideológica del protagonista, vista en tres partes cronológicas: "Flores de Lis" ambientada en la España aún monárquica, "Himno de Riego" en los años de la Segunda República, y "Hoz y martillo" en la Guerra. La tercera sección muestra el Madrid sometido por los republicanos determinados a identificar y neutralizar a todos elementos afines al ejército sublevado. La prosa de Foxá ofrece episodios de gran tensión dramática, en los que el protagonista se halla al borde de que su anexión política sea descubierta. El espíritu nacionalista de Foxá no ahorra en descripciones del terror. Curiosamente, el esposo de Pilar - la protagonista femenina-, de estirpe aristocrática, es asesinado por unos braceros en Extremadura, recurso temático que coincide con el episodio de la muerte del conde extremeño en Pascual Duarte.

La acción de Eugenio, de García Serrano, se desarrolla en los últimos días de la República y el epónimo protagonista muere en un tiroteo días antes del levantamiento. Narra el relato su amigo Rafael, que lo presenta como ejemplo de sacrificio y patriotismo. Esta novela se impregna de una estética de la violencia en que los héroes experimentan lo que se presenta como la brutalidad de la República ante la cual reaccionan con semejante virulencia y cuyo heroísmo consiste precisamente en sacrificarse en su lucha contrarrevolucionaria. En la novela se inserta incluso un escrito del protagonista, titulado "Pedagogía de la pistola", que dice que redactó después de matar a un comunista en defensa propia y mediante el cual denuncia el salvajismo republicano-marxista al tiempo que justifica el propio. Se trata, en definitiva, de una novela en que se presenta el régimen republicano como una sociedad sumida en el terror marxista en la cual el protagonista, 
ensalzado y santificado por el narrador, solamente puede existir plantándole cara. José-Carlos Mainer la ha denominado ejemplo de la "virulencia fascista" de "lejanas resonancias dannunzianas, wagnerianas o nietzcheanas"18 antes de señalar que "Resulta difícil leer sin repugnancia la prosa de García Serrano"19. Julio Rodríguez Puértolas ha resaltado igualmente la tendencia a la violencia y a la expresión nietzscheana y señalado la recurrencia a la sangre, el asesinato y la confrontación con los comunistas ${ }^{20}$. En definitiva, impregna la narración toda una exacerbada tendencia a la acción irracional, animalizada y a la muerte, que, como bien indica Mainer, producirá una gran impresión de verdadera repugnancia en los lectores. Como ejemplo análogo a Eugenio, Mainer pone Camisa azul (retrato de un falangista) (1938) de Felipe Ximénez de Sandoval. El relato arranca con el brutal asesinato, a manos de un grupo de republicanos, del hermano de la protagonista femenina, a quien sus camaradas falangistas prometen vengar ejecutando obreros. De Camisa azul resalta Mainer "la necesidad de violencia, la subversión contra el raciocinio" ${ }^{21}$. Vemos, en resumidas cuentas, que esa suerte de narración propensa al horror y la barbarie asesina en tiempos de la Guerra de España, escrita con el objeto de provocar una impresión de repulsa en los lectores, se institucionalizó inmediatamente antes de que Cela compusiese el Pascual Duarte.

Bajo la denominación "Crónicas de guerra y libros de memorias", Martínez Cachero ha agrupado una caudalosa corriente de relatos, la inmensa mayoría publicados en los años de la guerra. Especial interés revisten aquí las memorias compuestas por afec-

18 Mainer, José-Carlos: La corona hecha trizas. Una literatura en crisis, Barcelona, Crítica, 2008, pág. 175.

19 Ibid., 176.

20 Rodríguez Puértolas, Julio: Historia de la literatura fascista española, 2 vols. Madrid, Akal, 2008, pág. I, 303-304.

21 Mainer, José-Carlos: La corona hecha trizas, pág. 177. 
tos al levantamiento, en las que se denuncia la represión republicana, casi siempre en la ciudad de Madrid. Estos relatos se escriben en prosa novelesca, con lo que los hechos, que en su mayoría o su totalidad son reales, se envuelven a menudo en apariencia de literatura de ficción. En su estética violenta y antirrepublicana, se asemejan en mucho, por ejemplo, a las cuatro narraciones cortas de Concha Espina agrupadas bajo el título Luna roja. Entre estas memorias merece la pena resaltar Memorias de un finlandés (1939) de Leopoldo Huidobro, Cómo fui ejecutado en Madrid (1937) y El otro mundo (1938) de Jacinto Miquelarena, además de Madrid bajo el terror, 1936-1937. Impresiones de un evadido que estuvo a punto de ser fusilado (1937) y La agonía de Madrid (1938), ambas de Adelardo Fernández Arias. Aún así, la lista es extensa.

Uno de los primeros ejemplos es El preso 831. Del Madrid rojo. Últimos días de la Cárcel Modelo de Julio Guillén, publicado en 1937 anónimamente por temor a represalias contra los familiares del autor en zona republicana, y con abundancia de escenas de dolor y muerte ${ }^{22}$. Reconquista (1938) de Joaquín Alonso Bonet, libro de naturaleza memorialística en que se detallan las vivencias del autor en Asturias, con todo lujo de detalles referentes al trato inhumano - caracterizado por torturas físicas y psicológicasque la población de simpatías conservadoras y falangistas recibían de los republicanos. También en 1938 se publica Valencia roja de Salvador Ferrandis Luna, quien sufrió cautiverio en Valencia por su condición de empresario adinerado. Adelardo Fernández Arias publicó en 1937 Madrid bajo el terror, 1936-1937. Impresiones de un evadido que estuvo a punto de ser fusilado y en 1938 La agonía de Madrid. La primera refiere las peripecias del autor, quien salva la vida al evadirse de la cárcel de San Antón y hallar refugio en la embajada argentina ${ }^{23}$. En ambas se denuncia la deshumaniza-

22 Sobre la represión en la Cárcel Modelo véase Ruiz, Julius: Terror rojo, págs. 187-198.

23 Sobre la saca de San Antón (además de las de Ventas y Porlier) véase ibid., págs. 309-317. 
da represión republicana. Muchos de estos libros de memorias relatan vicisitudes en el Madrid republicano en que sus autores sufren persecución y alcanzan a escapar al disfrutar de asilo en alguna embajada. Esa es la trayectoria temática también de Memorias de un finlandés (1939) de Leopoldo Huidobro, quien se declara católico y monárquico, condición por la cual sufre persecución consiguiendo refugiarse en la embajada finlandesa, de la que también debe escapar, cuando esta es objeto del asalto de los republicanos, para esconderse en la noruega. A principios de la guerra, a Jacinto Miquelarena se le dio, erróneamente, por caído en la zona republicana. Resolvió entonces relatar sus experiencias en una narración que rememora sus días en el Madrid de los republicanos hasta el tiempo que discurrió en la zona nacional. La primera parte de Cómo fui ejecutado en Madrid se titula "Madrid" y ofrece una descripción detallada del terror que se vivía en la capital, con vivas descripciones de registros, detenciones, paseos y checas, todo lo cual recuerda poderosamente las novelas de Foxá y Borrás. Martínez Cachero observa "el desgarro esperpéntico" de dichas descripciones de ambientes ${ }^{24}$. El otro mundo acontece en Madrid y sigue las peripecias del autor-protagonista, oculto durante un tiempo en una embajada. Martínez Cachero ha reparado en el aire "escalofriante, acaso mejor tremendista" del capítulo $X$, donde se describe un fusilamiento en un callejón, y del capítulo XXIII, donde se detalla la desesperación del autor ante la desbocada la violencia marxista ${ }^{25}$.

En definitiva, ese tremendismo de Pascual Duarte comparte la estética de la literatura nacional de la guerra definida por la descripción de los horrores y la virulencia de la represión republicana, desde una conspicua y rampante perspectiva antirrepublicana y pronacional. No es de extrañar, pues, que Martínez Cachero haya advertido el "tremendismo" de El otro mundo de Miquelarena; antes bien, lo cierto es que ese tremendismo -o

24 Martínez Cachero, José María: Liras entre lanzas, pág. 101. 
prototremendismo como lo he llamado aquí- determinado por la violencia de resonancias nietzschanas, destinado a causar esa sensación de desasosiego y repugnancia en el lector, se fragua en la literatura compuesta por los nacionales durante la guerra e inmediatamente después, en obras como Chekas de Madrid de Borrás, La ciudad de Iribarren, Madrid, de corte a checa de Foxá o Eugenio de García Serrano, así como en esa letanía de memorias de guerra. El recurso temático del aristócrata asesinado en Extremadura por una algarada de campesinos partidarios de la República e inspirados en ideales revolucionarios marxistas, que Cela desarrolla en su primera novela, se halla ya en Madrid, de corte a checa. La recurrencia de este motivo, procedente de Foxá, en Pascual Duarte no parece ser una coincidencia. El objeto de Cela es - en parte o en todo- el mismo que el de Foxá y otros: denunciar el llamado terror rojo. Pero si Foxá y el resto de novelistas y de autores de memorias se limitan a presentar su versión de la situación vivida, Cela dispensa al tema un tratamiento más literario y novelesco, más psicológico, para lo cual se remonta a los orígenes del crimen, al objeto de mostrarnos un retrato psicológico del brazo ejecutor de los ideales revolucionarios republicanos.

En definitiva, el tremendismo de los años cuarenta, en que Pascual Duarte se inscribe, continúa la corriente de escritores nacionales como Carretero Novillo, Iribarren y Borrás, pero sobre todo, y al igual que estos, se asienta en una corriente literaria que emerge bajo una acentuada conciencia de lo que ya en 1935 Ernesto Giménez Caballero había denominado, en su Arte y Estado, la nacionalización cultural, esto es, la regulación del arte por medio de las estructuras estatales, que, en mayor o menor medida había sido una constante en la historia desde el siglo XVIII, pero de la que se adquirió una acentuada conciencia en esa década, especialmente en Italia ${ }^{26}$. Con Pascual Duarte, Cela se arrima al grupo de

26 Todo ello lo ha explicado José-Carlos Mainer en La corona hecha trizas, págs. $19-20$. 
autores afines a la España nacional que, durante la guerra e inmediatamente después de ella, habían ejercido la responsabilidad política de exaltación de la ideología con que comulgaban, que era aquella de los vencedores. En este sentido, Pascual Duarte y el tremendismo que le siguió continúan y culminan la suerte de literatura comprometida con la desacreditación de la República que prende en los primeros meses de la guerra y que, después del Primero de Abril del 39, viene a instaurar una verdadera nacionalización cultural, en la terminología de Giménez Caballero.

Habiéndose, por lo general, pasado por alto el entronque de Pascual Duarte con la literatura nacional de la guerra, los críticos han observado en ella un realismo de acendrado cuño que la ha entroncado con la picaresca. La consanguineidad picaresca de Pascual Duarte salta a la vista y a ella volveré más adelante. Consideremos, primero, el realismo de la primera novela de Cela. En el mismo Companion de Tamesis, Janet Pérez observa en esta novela la "aesthetic of the social novel" 27 . A ese realismo tremendista la crítica lo bautizó como "realismo existencial" de "expresionismo muy hispánico" ${ }^{\prime 28}$. El calificativo existencial caló hasta el punto de que Olga Ferrer llegó incluso a hallarle unas soterradas relaciones con el existencialismo ${ }^{29}$. Ello fue sopesado por Gonzalo Sobejano en su ensayo de título "Reflexiones sobre La familia de Pascual Duarte". Estima Sobejano que Pascual Duarte "constituye una primera tentativa de realismo existencial", del que escribe:

La consecuencia más general de la guerra, en lo que concierne a la novela, ha sido la adopción de este nuevo realismo: nuevo porque sobrepasa la observación costumbrista y el análisis descriptivo

27 Pérez, Janet: “The Social Realist Novel”, en Marta E. Alisent (ed.), A Companion to the Twentieth Century Spanish Novel, págs. 66-75, 66.

28 L. Boudreau Harold y John W. Kronik: “Introducción”, en Camilo José Cela, La familia de Pascual Duarte, Barcelona, Destino, 1989.

29 Ferrer, Olga P.: "La literatura española tremendista y su nexo con el existencialismo", Revista Hispánica Moderna, XXII, 3-4, 1956, págs. 297-303. 
del realismo decimonónico mediante una voluntad de testimonio objetivo artísticamente concentrado y social e históricamente centrado. En este nuevo realismo pueden señalarse dos direcciones: hacia la existencia del hombre español contemporáneo en aquellas situaciones que ponen a prueba la condición humana (realismo "existencial") y hacia el vivir de la colectividad española en estados y conflictos que revelan la presencia de una crisis y la urgencia de su solución (realismo "social") ${ }^{30}$.

A partir de ahí, Sobejano inserta Pascual Duarte en la corriente de ese realismo existencialista y le apostilla una larga lista de títulos salidos en los años cuarenta.

Sin embargo, la cuestión, o al menos la terminología empleada, se presta a controversia. A la literatura de principios del siglo XX también se la ha denominado "existencial" en cuanto que se concibió y se compuso bajo una óptica filosófica adelantada al existencialismo que ulteriormente prendería en Europa después de la Segunda Guerra Mundial. Decir que Pascual Duarte - o cualquier otra obra de filiación tremendista - propende al existencialismo que en años subsiguientes germinaría allende el Pirineo no es más que despejar las nieblas para contemplarla dentro del mapa literario de Europa. Antes bien, habremos de preguntarnos cómo y hasta qué punto las angustias de Pascual son más existencialistas que los desencantos vitales que obcecan a Fernando Ossorio en Camino de perfección (1902) o Andrés Hurtado en El árbol de la ciencia (1911), la melancólica obsesión de Antonio Azorín (el personaje) por el tiempo en Las confesiones de un pequeño filósofo (1904) o las amorosas remisiones de sus cartas en Antonio Azorín (1903), además, por supuesto, de las disquisiciones que con acento kierkegaardiano enuncia Augusto Pérez en Niebla (1914) ${ }^{31}$. Estos personajes se configuran como ejemplos

30 Sobejano, Gonzalo: "Reflexiones sobre La familia de Pascual Duarte", Papeles de Sons Armadans, XLVIII, 1968, págs. 19-58, 41.

31 Sobre la filosofía en autores como Baroja, Azorín y Unamuno, véase Johnson, Roberta: Crossfire. Philosophy and the Novel in Spain, 1900-1934, Lexington, The Uni- 
de lo se denomina el héroe decandente, esto es, una suerte de intelectual que pugna por hallar sentido a la existencia ${ }^{32}$. Pascual, evidentemente, es un personaje muy distinto a estos y se sitúa en una galaxia remotísima donde ningún atisbo de inquietud existencialista recuerda en modo alguno los pujos filosóficos de los héroes de Unamuno, Azorín y Baroja.

Por otro lado, y en relación con lo expuesto por Sobejano, cabe reparar en que "el análisis descriptivo del realismo decimonónico" (supra) fue precisamente sobrepasado por el realismo de los llamados noventayochistas, que torcieron la perspectiva realista hacia los hondones de contornos existencialistas y que, además, reflexionaron muy largo en torno a ese mismo "vivir de la colectividad española en estados de conflictos que revelan la presencia de una crisis y la urgencia de su solución" (supra). Repárese en las novelas escritas en los años inmediatamente posteriores al Desastre de 1898, aquellas en que se exponen las miserias de la sociedad española, se elevan hasta el cielo los lamentos por la postración social de la patria y se anhelan y orquestan prontas soluciones. Entre ellas podrían enumerarse las antedichas Camino de perfección y El árbol de la ciencia, además de otras obras barojianas como El mundo es ansí (1912), las de Azorín La voluntad (1902) y Antonio Azorín o, en plena Guerra de Cuba, La conquista del reino maya por Pío Cid (1896) y Los trabajos del infatigable creador Pío Cid (1898) de Ganivet. La Guerra Civil supuso, claro está, una traumática experiencia que marcó indeleblemente a los autores nuevos, como Cela y Delibes. La pérdida de Cuba, con la humillante derrota ante los Estados Unidos, supuso, a ojos de la opinión pública española, el episodio menos lustroso de la historia

versity Press of Kentucky, 1993. Sobre el caso concreto de Niebla refiero a Garrido Ardila, J. A.: "Nueva lectura de Niebla: Kierkegaard y el amor", Revista de Literatura, LXX, 139, 2008, págs. 83-115.

32 Sobre el héroe decadente en la literatura española de finales del siglo XIX y principios del XX véase Santiáñez, Nil: Investigaciones literarias: Modernidad, historia de la literatura y modernismos. Barcelona, Crítica, 2002, pág. 180. 
de España, a que los autores nuevos no pudieron sustraerse. Son dos momentos de crisis en que la novela comienza una nueva andadura. Ambos momentos se corresponden con otros análogos en Europa: la Primera Guerra Mundial - dos décadas después del 98- que sirvió a Virginia Woolf para fechar el momento de emulsión modernista, y la Guerra Civil con la Segunda Guerra Mundial.

Sentada la naturaleza realista-existencial de Pascual Duarte, Sobejano - en ese mismo trabajo - volvió la vista hacia los horizontes de la historia de la novela española y vislumbró en la picaresca de nuestros Siglos de Oro el antecedente literario más claro. No son pocos los trabajos en torno a la calidad picaresca de Pascual Duarte y todos, al unísono, la claman como el ejemplo sublime de la picaresca española contemporánea. The Cambridge History of Spanish Literature, por ejemplo, destaca de ella "a renewed use of an old form of Spanish prose - the Baroque picaresque" ${ }^{\prime 33}$. Y, en efecto, Cela se vale en su primera novela de una serie importante de características temáticas y formales del género picaresco. A los investigadores ha llamado especialmente la atención su estructura picaresca: el relato se concibe como una suerte de autobiografía, escrita en primera persona, dirigida a un narratario con el fin de narrar por extenso las circunstancias vitales que explican un caso, que aquí es el asesinato del conde. En virtud de todo ello, Antonio Rey Hazas ha escrito de ella que presenta "quizá el caso más claro de la supervivencia picaresca" en el siglo XX ${ }^{34}$. Otros muchos la han emparentado con el género del Lazarillo: Jorge Urrutia, Ernesto Giménez Caballero e Ignacio Soldevilla ${ }^{35}$. Otros observan difer-

33 Ugarte, Michael: “The Literature of Franco Spain, 1939-1975", en David T. Gies (ed.), The Cambridge History of Spanish Literature. Cambridge, Cambridge University Press, 2004, págs. 611-619, 614.

34 Antonio Rey Hazas, La novela picaresca. Madrid: Anaya, 1990, pág. 89.

35 Urrutia, Jorge: Cela: La familia de Pascual Duarte. Los contextos y el texto. Madrid, SGEL, 1982; Giménez Caballero, Ernesto: "Vagabundeo por la picaresca", La picaresca. Orígenes, textos, estructuras. Actas del Primer Congreso Internacional sobre Pi- 
encias significativas con los modelos del género, diferencias que obstan su justa afiliación a él ${ }^{36}$. De lo que no cabe duda es de que Cela halló en la picaresca una recia y modélica estructura novelística. Esas similitudes que la crítica ha apuntado emparentándola ora con el Lazarillo, ora con El Buscón, no son casuales, sino préstamos conscientes a que el autor recurre. Prueba esclarecedora de la estima que Cela profesaba a la picaresca hallamos en su tercera novela Nuevas andanzas y desventuras de Lazarillo de Tormes, una continuación, casi una reescritura, del clásico del Quinientos.

La dimensión picaresca de Pascual Duarte interesa asimismo por cuanto que contribuye y redunda en la proliferación de novelas ataviadas de picaresca producida por aquel entonces así en España como en otros países de nuestro entorno cultural. España engendra ejemplos tan ilustres como El chiplichandle. Acción picaresca (1940) de Juan Antonio de Zunzunegui y Lola, espejo oscuro (1950) de Darío Fernández Flórez. Fuera de España alimenta una corriente literaria que se ha dado en llamar neopicaresca y en la que se agrupan obras como The Invisible Man (1952) de Ralph Ellison, The Adventures of Augie March (1953) de Saul Bellow, Lucky Jim (1954) de Kingsley Amis, Felix Krull (1954) de Thomas Mann y Die Belchtrommel (1959) de Günter Grass ${ }^{37}$. Pero,

caresca., Manuel Criado de Val, coord. Madrid, Fundación Universitaria Española, 1979, págs. 935-952; Soldevilla Duarte, Ignacio: “Utilización de la tradición picaresca por Camilo José Cela", La picaresca. Orígenes, textos, estructuras. Actas del Primer Congreso Internacional sobre Picaresca, págs. 921-928.

36 Sobejano, Gonzalo: La novela española de nuestro tiempo: en busca del pueblo perdido. Madrid, Prensa Española, 1975, pág. 85; Brío Carretero, Clara del: “Técnica narrativa y configuración del protagonista en La familia de Pascual Duarte", EPOS, XVII, 2002, págs. 177-197; Garrido Ardila, J. A.: El género picaresco en la crítica literaria, Madrid, Biblioteca Nueva, 2008, págs. 150-155. En el tema ha vuelto a ahondar con precisión encomiable Rey Hazas, Antonio: "Picaresca, polisemia y modernidad: $\mathrm{La}$ familia de Pascual Duarte vista desde el Lazarillo de Tormes", Mostrar con propiedad un desatino: la novela española contemporánea, Antonio Rey Hazas, coord., Madrid, Eneida, 2004, págs. 113-150.

37 Aún resulta de mucha utilidad el libro de Sieber, Harry: The Picaresque. Londres, Methuen, 1977, donde se incluye una sección sobre la neopicaresca. 
sobre todo, interesa porque para hallar antecedentes picarescos a Pascual Duarte no es preciso remontarse tres siglos y pico. Aun cuando a Galdós se le haya relacionado con la picaresca ${ }^{38}$, las obras anteriores a Cela más en la línea de la picaresca quizá sean La busca, Mala hierba y Aurora roja (todas publicadas en 1903) de Baroja.

Manuel Alvar reconoció las importantes influencias literarias que Unamuno y Baroja ejercieron en los años posteriores a la guerra $^{39}$. El cotejo entre Pascual Duarte y La busca se revela esclarecedor en muchos sentidos, pero sobre todo por cuanto que muestra dos maneras muy similares de concebir la novela en un momento de cambios estéticos radicales. De La busca ha escrito Mary Bretz:

A través de los años 1900-1904, Baroja va acercándose a una forma novelística propia. A medida que acanza en la carrera se siente más seguro de su vocación y de las aspiraciones novelísticas. La desorientación estética de las primeras obras desaparece, se libra de las influencias ajenas y va elaborando una estética original. Tras el experimento modernista inicial, acude al impresionismo que luego abandona por el realismo, entendido de una forma muy distinta del realismo decimonónico y más compatible con la estética del siglo actual $^{40}$.

38 Por ejemplo, Juaristi, Jon: “Ironía, picaresca y parodia en La de Bringas”, Nueva Revista de Filología Hispánica, XXXVIII, 1, 1990, págs. 277-296; Correa, Gustavo: "El héroe de la picaresca y su influencia en la novela moderna española e hispanoamericana", Thesaurus, XXXII, 1, 1977, págs. 75-94 y "Galdós y la picaresca", Actas del primer congreso internacional de estudios Galdosianos, Las Palmas de Gran Canaria, Cabildo Insular de Gran Canaria, 1977, págs. 253-268

39 Manuel Alvar, en el capítulo "noventayochismo y novela de posguerra" de su De Galdós a Miguel Ángel Asturias. Madrid, Cátedra, 1976, págs. 169-205. Alvar resalta el influjo de Baroja y Unamuno en una serie de novelistas, como Gironella, Zunzunegui, Soler y el mismo Cela.

40 Bretz, Mary Lee: La evolución novelística de Pío Baroja. Madrid, José Porrúa Turanzas, 1979, pág. 220. 
La cita viene a cuento por cuanto que recuerda aquella de Sobejano (supra) en torno a la superación del realismo decimonónico. Al igual que Pascual Duarte, ese realismo barojiano se vetea de rasgos picarescos y se atavía de "la estética del siglo actual". Cela no da con la fórmula luego de forjarse una trayectoria novelística, pero lo cierto es que esa fórmula coincide substancialmente con la de Baroja, aun cuando ambas obras se diferencien la una de la otra en elementos muy varios. En un estudio sobre $L a$ busca, ha observado Fernando Varela una tríada de elementos no realistas que la definen: 1) "el autor enfoca solamente los aspectos más negativos de la miseria del suburbio" 41 , 2) "la insistencia en la caricatura $[. .$.$] de unos personajes que recuerdan ligera-$ mente los esperpentos goyescos" 42 y 3) que los "personajes se rebelen contra la injusticia"43. Los paralelismos con Pascual Duarte saltan a la vista. Cela enfoca exclusivamente los aspectos más negativos de la vida de Pascual y de su entorno, con la intención y el propósito de pintar un paisaje de las miserias menos llevaderas en la España de la Restauración y de la zona republicana durante la guerra. Se recrea asimismo en la caricatura de luces esperpénticas, por ejemplo en las descripciones deshumanizadas y animalizadas de Mario, en las escenas en que las tres mujeres murmuran contra él (según él cree) como si fuesen brujas. No en vano Sobejano ha llamado la atención sobre la literatura en la línea del romance popular y "la tragedia rural mítica al modo de Valle-Inclán (Tragedia de ensueño, El embrujado)"44. Por último, Pascual se rebela en sentidos muy varios contra las injusticias (o lo que él estima que son injusticias), por ejemplo la injusticia de que se le reduzca la pena por el asesinato del Estirao, que le

41 Valera Iglesias, Fernando: Baroja, epígono del Romanticismo. Viena, Romanistik, 2007, pág. 39.

42 Ibid, pág. 41.

43 Ibid., pág. 42 .

44 Sobejano, "Reflexiónes sobre La familia de Pascual Duarte", pág. 45. 
llevará a volver a matar, o la injusticia (implícita) de que, según él declara, Dios le haya perdonado y la justicia terrena no. Se trata de una suerte de realismo muy similar al barojiano y, como en $L a$ busca, de regusto picaresco.

Vemos, pues, que no hay que retrotraerse tres centurias para hallar novelas picarescas españolas de estética picaresca similar a Pascual Duarte. Se trata de la misma (o similar) suerte de novela, que en referencia a la trilogía La lucha por la vida Sobejano denominó precisamente "novela social" y que el mismo Sobejano definiría como aquella que "describe la vida colectiva de una clase o sector desde un punto de vista principalmente económico" 45 . En Pascual Duarte se describe la vida del protagonista y su entorno social, desde un punto de vista marcadamente económico. Recuérdese, por ejemplo, que Pascual es feliz cuando se gasta todos sus ahorros para vivir a cuerpo de rey durante la luna de miel, o el contraste con el adinerado don Jesús (contraste en la descripción de sus respectivas casas).

El realismo de Pascual Duarte merece calificarse de harto más complejo que una mera reflexión de acento existencial o existencialista de pujos picarescos. Mallo ha reparado en que tan relevante resulta lo que el narrador dice como lo que calla, técnica propia asimismo de algunas narraciones de Ana María Matute, de El Jarama (1955) de Rafael Sánchez Ferlosio y de Señas de identidad (1966) de Juan Goytisolo ${ }^{46}$. Al respecto resaltó Jo Evans de Pascual Duarte "the evasiveness of the narrative and its narrador" ${ }^{47}$. Ello, evidentemente, tiene que ver con la cuestión de la índole de realismo que Cela adopta en la novela. En los ambientes descritos al

45 Sobejano, Gonzalo: "Vigencia de la novela barojiana", Los Baroja. Memoria y lección, Varios Autores, San Sebastián, Fundación Kutxa, 1998, págs. 137-151, 141.

46 Mallo, “Caracterización y valor del 'tremendismo' en la novela española contemporánea", pág. 49.

47 Evans, Jo: "La familia de Pascual Duarte and the Search for Gendered Identity", Bulletin of Hispanic Studies, LXXI, 1994, págs. 197-216, 197. 
principio del relato, el autor pinta un cuadro preñado de símbolos. Sirvan de ejemplo los binomios formados por la iglesia y la casa de don Jesús en el centro del pueblo frente a la casucha de Pascual en la periferia, además de la imagen del gavilán y la cigüeña cojita. El autor (por medio del narrador) abona su descripción con símbolos y referencias que perfilan, en la percepción del lector, la tesis que el personaje pretende presentar: que él es la verdadera víctima, porque la sociedad lo segregó (como simboliza su casa en las afueras del pueblo ${ }^{48}$ ), que él es la inofensiva cigüeña que cayó presa del terrible gavilán, que es la sociedad misma. Esa es la tesis del personaje, tesis que el autor construye para, paralelamente, derribar por medio de los paratextos, en los cuales el transcriptor, don Joaquín, don Santiago el presbítero y Césareo Martín el comandante del puesto de la Guardia Civil, todos a un tiempo, lo condenan sin ambages ni remilgos. Se trata de un realismo de apariencia objetiva que, sin embargo, peca del mismo subjetivismo que el realismo social que vendría una década después. Pero, sobre todo, es una suerte de realismo muy en la línea de la primera picaresca, sobre todo de El Buscón, novela en que el autor dispone que el personaje se traicione a sí mismo autorretratándose con todas sus míseras (a ojos de Quevedo) ansias de ascenso social puestas en la aristocracia $^{49}$.

Esa técnica descriptiva se repite a menudo a lo largo del relato. En el capítulo 8 Pascual relata su boda, el viaje de novios a Mérida y el regreso. La mayor parte del espacio cronológico que

48 Recuérdese también que la palabra civilización procede del latín civitas. Al ubicar su hogar en las afueras del pueblo, el narrador se sitúa fuera de la civilización.

49 Sobre este tema véanse Redondo, Agustín: “Del personaje de don Diego Coronel a una nueva interpretación de El Buscón", Actas del Quinto Congreso Internacional de Hispanistas. François López, Joseph Pérez, Noel Salomón, Maxime Chevalier, coord., Burdeos, Asociación Internacional de Hispanistas, 1974. 699-711; Antonio Rey Hazas, "El Buscón: luces y sombras de una obra genial”, en Deslindes de la novela picaresca. Málaga, Universidad de Málaga, 2003, págs. 109-204. Sobre el empleo de técnicas picarescas versa mi trabajo "Perspectivismo narrativo y enjuiciamiento social en La familia de Pascual Duarte", Romance Quarterly, 2014, en prensa. 
discurre en Mérida se centra en la descripción de la habitación en la casa de huéspedes donde se alojan: alcoba amueblada con gusto y repleta de objetos decorativos, como el reloj, las castañuelas, el cromo, etc. De la luna de miel no dice nada más. Apunta que "para nada salíamos a la calle" (87). Después del descriptivo arrebato de pasión de Pascual y Lola sobre la tumba de Mario, el tiempo narrativo entra en una elipsis que se llena con la descripción que sirve para que el lector aprenda que Pascual sabe apreciar el buen vivir y que el buen vivir (del cual el destino le privó al hacerle nacer en la casa de la periferia) le convertía en mejor persona, pero también oculta el comportamiento sexual del protagonista. Danse en este pasaje dos perspectivas: la del narrador que describe su apreciación del lujo para así mostrarse como un ser bueno; la del autor que hace que su narrador evite entrar en detalles y cuyo silencio connota algo malo: si no han salido de la alcoba a saber en qué prácticas sicalípticas se habrán ocupado después de la escena, rayana en el sadismo, sobre la tumba de Mario $^{50}$.

El segundo ejemplo se halla en el capítulo 1, en la descripción de la casa de sus padres. Escribe entonces que adornaban las paredes "un calendario muy bonito que representaba una joven abanicándose sobre una barca y debajo de la cual se leía en letras que parecían de polvillo de plata, 'Modesto Rodríguez. Ultramarinos finos. Mérida (Badajoz)'” (30), un retrato de Espartero y "tres o cuatro fotografías [...] de no sé quién" (30). Acaba refiriéndose a "un reló despertador" que "siempre funcionó como Dios manda" (30). Tan minuciosa descripción pone de relieve lo que el narrador había expresado en ese mismo párrafo: que la casa "correspondía a mi posición" (30), pero también descubre,

50 Recuérdese aquí la elipsis de Lázaro en el tratado IV, del que apenas dice que sirvió a un fraile de La Merced a quien describe con una recua de ironías, y acaba: "Y por esto y por otras cosillas que no digo, salí dél", lo cual ha dado lugar a interpretaciones de todo tipo respecto de las aficiones sexuales del fraile y cómo hubiese podido abusar de Lazarillo. La cita se halla en Lazarillo de Tormes, Madrid, Cátedra, 1998, pág. 111. 
por omisión, la catadura moral de su familia y de él mismo. Ninguna casa cristiana de aquel tiempo prescindiría de, al menos, una imagen religiosa, como sí la hay en la habitación de la posada del Mirlo en Mérida. Esto es, que el narrador describe con un motivo - argüir su pobreza como atenuante de su carrera asesina- pero, en realidad, el autor emplea esa misma descripción para lograr lo contrario - resaltar su condición de ateo, displicente para la moral de la época-.

Se trata de un realismo increíblemente irónico que contribuye a lo que críticos de todo origen han resaltado en Pascual Duarte: la embargadora ironía que dificulta sobremanera determinar si al protagonista debe juzgarse o víctima de la sociedad o enemigo público. La cuestión se da ya en la picaresca del Siglo de Oro, pero es característica de la novela de las décadas inmediatamente anteriores a la publicación de Pascual Duarte. La representación de la realidad irónica caracteriza la novela modernista. A esa suerte de novelas preñadas de ironía anfibológica se las denominó, merced al concepto nietzscheano del rostro de Jano, novelas jánicas, o de doble faz ${ }^{51}$. Esta profunda anfibología en la semántica de Pascual Duarte halla su precedente más claro e ilustre en una novela publicada apenas once años antes: San Manuel Bueno, mártir (1931), de Unamuno. En San Manuel, una narradora presenta la historia del epónimo protagonista y plantea la posibilidad de que el sacerdote canonizado hubiese en vida dudado secretamente de la existencia de la vida eterna. Las apreciaciones críticas en torno a esta novela son análogas a las de Pascual Duarte: parte de la crítica ha presentado al protagonista como ateo convencido mientras que otros han esgrimido el principio de duda razonable para sugerir que, en realidad y a pesar de lo

51 Kuna, Franz: “The Janus-Faced Novel: Conrad, Musil, Kafka, Mann”, Modernism. A Guide to European Literature. 1890-1930, Malcolm Bradbury y James McFarlane, coord., Londres, Penguin, 1991, págs. 443-452, donde se apunta, por ejemplo: "the Janus face, at once Dionysiac and Apollonian, of the Aeschlyan Prometheus ... Whatever exists is both just and unjust, and equally justified in both" (pág. 444). 
que dice la narradora, el buen sacerdote, en el fondo, creía ${ }^{52}$. A más de ello, en la historia de San Manuel, que tradicionalmente se ha leído como un relato centrado en la cuestión de la fe del protagonista, se ha columbrado asimismo un relato paralelo: la historia del enamoramiento de la narradora y el epónimo protagonista $^{53}$. El efecto es idéntico a Pascual Duarte: en ambas novelas se urde una realidad que se presta a dos interpretaciones irreconciliables, hasta el punto de que a día de hoy no se ha producido consenso alguno entre los estudiosos que han analizado ambas novelas y que defienden interpretaciones opuestas ${ }^{54}$.

Muy parejas son, igualmente, las técnicas narrativas. En San Manuel, la revelación de que el sacerdote no cree llega al lector a través de dos intermediarios: según escribe la narradora, San Manuel hace la confesión a Lázaro, Lázaro se la transmite a ella, y ella lo revela en su escrito. De esta suerte la realidad atraviesa por una serie de dos personajes que la interpretan y la presentan, deformándola de este modo o, al menos, produciendo en el lector una sensación de duda. En Pascual Duarte el mismo protagonista advierte de que su memoria (según él) pudiese distorsionar la veracidad de los datos que refiere cuando recuerda las prédicas que recibió del párroco: “Bueno, no me lo dijo así; me

52 Entre quienes rechazan la fe a San Manuel se cuenta Zahareas, Anthony N.: "Unamuno's Marxian Slip: Religion as Opium for the People", The Journal of the Midwest Modern Language Association, XVII, 1984, págs. 16-37. De la opinión contraria son Vauthier, Bénédicte: "Huellas del ideario (religioso) krausista en San Manuel Bueno, mártir de Miguel de Unamuno", Cuadernos de la Cátedra Miguel de Unamuno, XXXIII, 1998, págs. 145-189, y Longhurst, C. A.: “The Problem of Truth in San Manuel Bueno, mártir", The Modern Language Review, LXXVI, 3, 1981, págs. 581-597. Vauthier pone la historia en relación con el humanismo racional del krausismo. Longhurst recapacita en torno al papel de la narradora como narradora infidente.

53 Apud Longhurst, "The Problem of Truth in San Manuel Bueno, mártir", y Garrido Ardila, J. A.: "Amor y religión en San Manuel Bueno, mártir de Unamuno", Romance Quarterly, LVIII, 2011, págs. 94-113.

54 Lo cual da para un estudio detallado que se escapa a las dimensiones de este. Baste por ahora, como apuntaba, llamar la atención sobre esta característica para la contextualización de Pascual Duarte en la tradición literaria. 
lo dijo con unas palabras muy justas y cabales, pero lo que me quiso decir no andaría, sobre poco más o menos, muy alejado de lo que dejo escrito" (57). Aquí, el mismo narrador se declara infidente y advierte de que el lector se halla ante una interpretación de la realidad. La ambigüedad del relato propicia que, tanto en la novela de Unamuno como en la de Cela, se dispongan sendos personajes que deciden darlo a la imprenta luego de ejercer de correctores y preparadores del texto.

San Manuel comienza con el relato de Ángela, la narradora. En las postrimerías del relato, y sin que se anuncie por medio de una escisión capitular, la voz de la narradora da paso a la de un tercero que se dirige a un "lector": “Cómo vino a parar a mis manos este documento, esta memoria a Ángela Carballino? He aquí algo, lector, algo que debo guardar en secreto. Te la doy tal y como a mí me ha llegado, sin más que corregir pocas, muy pocas particularidades de la redacción" ${ }^{\prime 5}$. El recurso del relato hallado y dado a la imprenta se remonta a la Edad Media, a textos como Cárcel de amor de San Pedro. En el Quijote se presenta ese mismo recurso con el añadido de la posible distorsión del manuscrito al aumentarse el número de intermediarios entre el emisor de la información y el lector implícito: Cide Hamete lo redacta, el mozo toledano lo traduce y el narrador lo retoca y pone en las manos del lector. En San Manuel, Unamuno prescinde de los paratextos a que tan dado era, por ejemplo en Niebla, que va precedida del "Prólogo" de Víctor Goti, el "Post-prólogo" de Unamuno y la apostilla del "Epílogo" de Orfeo, el perro del protagonista. Cela sí recurrirá a la parafernalia paratextual mediante la nota del transcriptor, el testamento de don Joaquín y las cartas de don Santiago y de Cesáreo Martín.

La importancia en el uso de los paratextos reside en que Cela los emplea para enfatizar la naturaleza jánica de su obra. El personaje que asoma en las postrimerías de San Manuel nos infor167.

55 Unamuno, Miguel de: San Manuel Bueno, mártir. Madrid, Cátedra, 2005, pág. 
ma del misterioso hallazgo del manuscrito, de que ha obrado en él algunas correcciones gramaticales sin importancia, antes de realizar un juicio interpretativo del relato de la narradora, como afirma: "Quiero también, ya que Ángela Carballino mezcló a su relato sus propios sentimientos, ni sé qué otra cosa quepa, comentar yo aquí lo que ella dejó dicho de que si don Manuel y su discípulo Lázaro hubiesen confesado al pueblo su estado de creencia [...]" ${ }^{\prime 56}$. La disposición de los paratextos en Pascual Duarte cumple idéntica función. En la "Nota del transcriptor" este afirma que ha ido "traduciendo y ordenando" (17) y especifica: "no me corresponde sino la transcripción; no he corregido ni añadido una tilde, porque he querido respetar el relato hasta en su estilo" (18). A renglón seguido afirma que ha recurrido a "la tijera y cortar por lo sano" (18) en aquellos pasajes "demasiado crudos" (18). El transcriptor hace el trabajo de los censores de la época, para justificar el relato pero también para acentuar la infidencia del mismo: el lector se las verá con un narrador infidente cuyo texto ha sido podado por un transcriptor (también) infidente. Al manuscrito de Pascual apostilla el transcriptor tres documentos: "Otra nota del transcriptor" y las sendas cartas de don Santiago y de Cesáreo Martín. Esa "Otra nota" sirve al transcriptor para enjuiciar al protagonista, de igual guisa que el transcriptor de San Manuel enjuicia al santo. El transcriptor unamuniano recurre a citas bíblicas que el lector habrá de interpretar; el de Cela será contundente: del uso de la tinta en la carta de Pascual colige que la escribió con intención, "precaución que nos presenta a nuestro personaje no tan olvidadizo ni atontado como a primera vista pareciera" (179). Esa acusación refuerza la ambigüedad del relato, reforzado después con las dispares versiones de la ejecución del reo según las plumas del presbítero y del guardia civil.

Los paratextos redundan asimismo en la composición de la narración fragmentada. El texto se llena de elipsis, por ejemplo en el capítulo 12, en que Lola reprocha a Pascual la vida que 
han tenido. Una cantidad considerable de capítulos finalizan en puntos suspensivos ${ }^{57}$. El orden de los acontecimientos se altera, siendo el mejor ejemplo de ello, quizá, la muerte de Chispa ${ }^{58}$. Ello posee una relevancia tal para el autor que incluso hace que su narrador lo admita cuando, al abrir el capítulo 4 declara al narratario:

Usted sabrá disculpar el poco orden que llevo en el relato, que por eso de seguir por la persona y no por el tiempo me hace andar saltando del principio al fin y del fin a los principios como langosta vareada, pero resulta que de manera alguna, que ésta no sea, podría llevarlo, ya que lo que suelto como me sale y a las mientes me viene, sin pararme a construirlo como una novela, ya que, a más de que probablemente no me saldría, siempre estaría a pique del peligro que me daría el empezar a hablar y a hablar para quedarme de pronto tan ahogado y tan parado que no supiera por dónde salir (54).

El narrador establece una distinción entre su relato y una novela en función de la disposición de la diégesis. Pascual se refiere aquí a las novelas realistas decimonónicas, de diégesis lineal y que siguen un trazado en función del desarrollo cronológico. El relato de Pascual no es una novela porque no sigue esa disposición linear: sigue a las personas (fundamentalmente al protagonista) y el desarrollo psicológico de ellas, acaba los capítulos en puntos suspensivos, y el transcriptor poda con las tijeras. El resultado es una narración fragmentada, elíptica y revestida de un hábito de paratextos que juzgan el relato y la moralidad del protagonista. En efecto, no se corresponde con la concepción del género de la novela según la estética realista, pero constituye una novela deu-

57 Como advirtió Germán Gullón, “Contexto ideológico y forma narrativa en La familia de Pascual Duarte: en busca de una perspectiva lectorial", Hispania, LXVIII.1, 1985, págs. 1-8.

58 Véase Luis T. González del Valle, “La muerte de Chispa: su función en La familia de Pascual Duarte", Sin Nombre, VI, 1975, págs. 56-58 
dora de la estética del modernismo. La narración fragmentada es característica de Pascual Duarte que preludia la construcción de La colmena, pero es, asimismo, característica esencial de novelas anteriores como El obispo leproso (1926) de Miró o la misma San Manuel de Unamuno.

En definitiva, Pascual Duarte establece el punto de partida de la novela de postguerra por cuanto que es la primera obra maestra con rango de clásico que se publica tras la contienda. Sin embargo, no debe tenerse por texto que cambia el curso de la historia de la novela española, sino por novela que continúa las corrientes novelísticas inmediatamente anteriores. Adopta el tremendismo que se había fraguado en las novelas de la guerra y que cobró forma en la sucesión de obras de gentes como García Serrano, Iribarren y Borrás, y lo emplea con la misma intención política. En su forma, Pascual Duarte sigue la presentación relativa y ambigua de una realidad al modo de las novelas jánicas del modernismo y con técnicas que ya había empleado Unamuno en San Manuel ${ }^{59}$. De la novela modernista toma asimismo la disposición fragmentada de la trama. De la picaresca prístina obtiene una serie de recursos formales, pero la utiliza como Baroja la utilizase en otro momento clave en el devenir de la historia y de la literatura españolas. Pascual Duarte se erige, así, en la trabazón que liga la novela modernista de antes de la guerra, principalmente la ambigüedad jánica de Unamuno y la picaresca de Baroja - amén de la picaresca clásica-, con la novela de la postguerra.

Juan Antonio Garrido Ardila

UNIVERSIDAD DE EDIMBURGo

59 Añádase a todo ello lo apuntado por Sobejano en "Reflexiones sobre La familia de Pascual Duarte", especialmente las resonancias del esperpento valle-inclaniano. 